\title{
Democracy and consensus decision-making among the Bemba-speaking people of Zambia: An African theological perspective
}

\begin{abstract}
Author:
Simon Muwowo ${ }^{1}$

Affiliation:

${ }^{1}$ Department of Dogmatics

and Christian Ethics,

University of Pretoria,

South Africa

Project Leader: V.S. Vellem Project Number: 04425030

Description:

Dr Muwowo is part of the research project, 'Social Cohesion', directed by Prof Dr. Vuyani Vellem of the Department of Dogmatics and Christian Ethics, Faculty of Theology, University of

Pretoria.
\end{abstract}

\section{Corresponding author:}

Simon Muwowo,

smuwowo2002@yahoo.com

\section{Dates:}

Received: 23 June 2015 Accepted: 17 Mar. 2016

Published: 19 Aug. 2016

How to cite this article: Muwowo, S., 2016,

'Democracy and consensus decision-making among the Bemba-speaking people of Zambia: An African theological perspective', HTS Teologiese Studies/ Theological Studies 72(1), a3090. http://dx.doi. org/10.4102/hts.v72i1.3090

\section{Copyright:}

(c) 2016. The Authors.

Licensee: AOSIS. This work is licensed under the Creative Commons Attribution License.

\section{Read online:}

Scan this QR
code with your
smart phone or
mobile device
to read online.

\begin{abstract}
This article contributes to a critical assessment of the concept of democracy and consensus decision-making of the Bemba matrilineal governance system as a basis for a democratic model of engagement in African politics from an African theological perspective. It is of the opinion that assessing the concept of democracy by consensus decision-making of the Bemba provides a dialogue between the African traditional governance systems as a viable form of political governance ideal for multi-ethnic countries such as Zambia. This is a pinnacle of the 21st century debate which elaborates the important task of African Christian Theology in the rehabilitation, or renovation process of politics of identity for an authentic governance system with authentic African flavour for African governance systems.
\end{abstract}

\section{Introduction}

This article proposes an emergence of an alternative paradigm of democracy based on the matrilineal governance system of the Bemba-speaking people of Zambia as a remedial model of democracy in Zambia. In contrast to multiparty democracy, which evidentially promotes political division, the proposed model would potentially be a better model of democratic governance and an enhancement of human rights in Zambia. By using an African theological approach to governance ethics, the article explores inwards to appropriate indigenous democratic ideals and values associated with the Bemba governance system. It is within that demonstrative understanding that the article argues for a non-party consensual democracy that is based on the governance system of the Bemba as a remedial critique to the current model of democracy that is fraught with problems bedevilling contemporary Zambia especially the political problem of ethnic and tribal differences today. It should be critically noted here that this attempt is externally induced by the urge to demonstrate that the Bemba traditional political system, among other African tribes, had a similar experience with 'some western states where consensual democracy is the adopted model such as New Zealand and East Timor' (Fayemi 2010:1) based on the foundation of Jurgen Harbamas (born 18 June 1929) whose theory on deliberative democracy and communicative rationality in the public sphere sets a basis for consensus democracy as a model of governance that promotes mutual interests for the benefit of all parties. This article concludes that, if well harnessed, the traditional African governance system of democracy by consensus has great potential to bring about political stability, accommodate diverse interests and accelerate social and economic development in all parts of Zambia without being bias towards any particular tribe or region.

\section{Point of departure}

Zambia among other African nations is a product of African traditional governance systems whose foundations were anchored on traditional democracy whereby the elders settled the affairs of the people 'through rational discussions' (Rohio 1975:478).

It is beyond reasonable doubt that 'throughout the African Diaspora during the pre-colonial era, African political systems were essentially democratic' (Bradley 2005:414). By the pre-colonial era, I refer to the period 'prior to the Berlin conference of November 1884-February 1885' (Bradley 2005:414) which paved the way for the scramble for Africa by European powers for 'their own colonial interests' (Bradley 2005:414). As recorded by several anthropologists, there is strong 'evidence of democratic governance in indigenous African states' (Bradley 2005:414; Busia 1967), which when rehabilitated after a long period of abandonment would demonstrate a true governance system that

Note: Rev. Dr Simon Muwowo was a Doctoral student of Prof. Dr Vuyani Vellem, professor of Dogmatics and Christian Ethics, University of Pretoria. This article is based on a dissertation written by the author as part of the fulfilment of the requirements for the PhD degree at the University of Pretoria, completed in 2015 under the supervision of Prof. Dr Vellem. 
would be consistent with the nature and culture of 'the homo Afrikanus'. (Pobee 1979:43-52). The main argument for the democratic nature of the pre-colonial African societies awes to the fact that although they could not be perceived as democratic from the Western lenses, in the meaning of the word today they were democratic in the sense that 'they exhibited all the common characteristics of consent of the people and a balance between centralised and decentralised power, all intended to prevent the abuse of authority by any one person' (Osabu-kle 2000). It should however be noted that sometimes 'the systems did manifest exclusion, for instance elitism and male domination' (Bradley 2005:414) but these are the areas that in the rehabilitation process of African governance would be taken into consideration in order to meet the standards of modern society within the tenets of the African ethos.

It is out of this profound history of Africa's democratic value system that the article endeavours to formulate an ethicaltheological frame work to guide the proposal for a non-party democracy by consensus as a new direction for a Zambian African political system. It is a theological framework owing to the fact that Zambia's peculiar constitutional provision as 'a Christian nation by declaration' (Muwowo 2010) attracts a theological approach to its democratic model uniquely coined with the African traditional system of governance referred to above.

It is the article's firm contention that 'democracy is a configuration of governance molded by the general values biases and nuances of a given culture' (Bradley 2005:415). As a matter of fact, every governance system is 'culturally determined' (Muwowo 2010) and as such I envisage that the reality of Zambia's democracy is rightly positioned within the cultural context of the Zambian people within the African continent. Arising from this stand point, Zambia can be perceived as a nation on crossroads with regard to the pursuit of a truly Zambian-African democratic system owing to the following:

- It is an African nation whose constitutional provision depicts the Christian value system as a principle of nationhood. Whether, this is feasible, remains a matter of theological interest.

- It is an African nation whose foundation and ethos are purely informed by African tradition and cultural practices.

- It is a multi-ethnic country with several ethnic groups whose tribal and ethnic inclinations of the people more often than not antagonise against each other.

With these reasons, it calls for serious theological and ethical thinking in the formulation of a moral framework or guide that, by and large, informs the Zambian situation if indeed the proposition of a non-party model of democracy by consensus is to be feasible in the Zambian situation.

\section{Methodology}

Methodologically, I am inspired by the contribution of John S. Pobee, a renowned African theologian, as a model for my approach to this proposal. In his book Toward an African theology (1979), Pobee in a statement of dialogue between Christianity and African traditional cultures, among the Akan tribes of Ghana, defined 'A homo Afrikanus as a multi-headed hydra, displaying varieties not only vis-à-vis the non- African but also vis-a-vis other species of a homo Afrikanus' (1979:43-52). I view this definition as opening another dimension of understanding that an African person is created with a plural disposition which engages divergent models to achieve its desired goals. Now if politics are 'culturally determined' (Muwowo 2010) as defined by many cultural protagonists, then the failure of Western multiparty democracy practised in Zambia is justified. It has not been rooted in the hearts and minds of the people as it is a foreign undertaking.

I have widely used Pobee's definition of a homo Afrikanus as a 'multi-headed hydra' (Muwowo 2010) as a point of departure towards an indigenous Zambian-African plural democracy referred to as 'democracy by consensus', which was first propounded by Kwasi Wiredu (1996:180-190) being proposed for the progression of Zambian politics. It is my argument that in order to develop and sustain a democracy, which in its simplest terms means 'a government of the people by the people' (Mutiso 1975:478), in Zambia which demonstrates the reality of an African culture in governance, an African multifaceted nature which is evidenced in the gift of Africa's, 'different stocks of languages, clans, and cultures needs to be appreciated' (Pobee 1979:44). My opinion in the metaphor of an African society as a 'multi-headed hydra' (Pobee 1979:43) needs to adhere to a full concept of the principle of consensus as a premeditated option to achieve a truly African governance system. Our argument is that, in an African society, the expectations of the members of society are the same and they are based on the foundation of 'prosperity, fecundity and good health' (Bwalya 2012). We do however take note that it is possible that 'though the immediate perceptions of these interests may be different', (Wiredu 1996:180) the goal is the same. We have considered a 'multi-headed hydra' (Linebaugh 2000), an animal with many heads all 'locked up in a struggle for food but if they could, but see that the food was actually destined for the same stomach, the irrationality of the conflict would manifest in them that would lead to an ideal solution' (Wiredu 2000:5). Our hypothesis question in this regard is, 'Is there a chance for a solution?' (Wiredu 2000). It should be noted that the answer to every question in African society lies in the concept of Ubuntu and that is, 'human beings have the ability to cut through their differences to the rock bottom identity of interests' (Wiredu 2000). And, on this view, 'the means to that objective is simply rational discussion (Mutiso 1975:478). On the capabilities of this means, the African society is very explicit. They say that there is 'no problem of human relations that cannot be resolved by dialogue' (Mutiso 1975:478). This is what Kaunda, former president of Zambia meant when he said, 'in our African society solutions were arrived at through consensus' (Mutiso 1975:476).

Dialogue, presupposes not just two parties (at least), but also two conflicting positions as the 'Multi-headed hydra' 
metaphor describes the nature of a homo Afrikanus. 'One head does not hold council, nor was any suggestion that one voice might be entitled to be heard to the exclusion of others countenanced for one moment' (Wiredu 1996:180). A Bemba saying also states, Umunwe umo tausalanda (Mpashi 1970) [one finger cannot pick head lice], says another Bemba saying. They also say Amano mambulwa kabili yafuma Mwifwesa yaya mu Culu (Mpashi 1970) [words of wisdom are from one person to the other, even more wisdom comes from a pot stand to an anthill]. These Bemba parables presuppose the idea of the principle of consensus as a basic foundation of any successful concept of governance in an African society.

With this value system in traditional political governance, we approach my argument with the Bemba model to political governance in Zambia. I chose the Bemba model based on research findings by Andrew Roberts (1973), who unequivocally states:

the Bemba's are a very unique tribe as their entire political system, is 'multi-ethnic', 'multi-clan' and comprises those people and tribes who consider themselves as subjects of Chitimukulu, the Bemba paramount Chief. (p. xxvii)

It is therefore an interesting level of engagement for an appropriate Zambian polity. Historically, the Bemba tribe is regarded as being, 'the most culturally and politically assertive in Zambia' (Roberts 1973). Their origins from 'the Lunda-Luba multi-ethnic empire that had once flourished in the seventh century in the Congo basin' (Roberts 1973) empowers my argument on the unification of a plural governance system that has successfully administered it affairs for over 300 years in the present Zambia, without major disruptions and disputes. Demographically Zambia is heavily populated by the Lunda-Luba tribal offshoots, scattered across Luapula, Northern, Muchinga, Copperbelt, North Western and Central Provinces. There still exist cultural and linguistic affinities among the diverse tribes found in these regions however.

\section{Main argument}

This article argues that the consensus principle of governance based on the practice of the Bemba concept of traditional governance system is the right path for a Zambian plural polity that will avoid, both, 'the authoritarian one party system and the multiparty system' (Wiredu 1996:180) of governance influenced by Western ideologies which, by and large, 'is obnoxious' (Wiredu 1996). As a political decision procedure, it is argued that the consensus principle bases its decisions 'not based on the majoritarian vote' (Wiredu 2000:5) influence but takes care of the reasoning of the minority in society or country and in that case, democracy takes its original meaning as it incorporates all citizens in decisionmaking in the running of the countries affairs. The concept is 'that each representative of the people should be persuaded, if not of the optimality of each decision, at least of its practical necessity, all things considered' (Wiredu 1996:189).

We wish to demonstrate that the Bemba traditional political system was based on Chieftainship. Every lineage in Ulubemba districts, that is, Lubemba country including the Paramount Chief Chitimukulu had been elected by consensus on grounds of 'maturity, reputation of wisdom and rhetoric abilities' (Mwamba 2006:12). The idea of seniority in society or lineage 'was sometimes considered but not as a perquisite to the former' (Roberts 1973). Lineage, according to the Bemba, meant all individuals of the royal clan of 'Abena $\mathrm{Ng}^{\prime}$ 'andu of the Crocodile (Nquena) clan' (Roberts 1973). The association of the lineage heads form the local government council, called Bashilubemba, who are the priests and the hereditary councillors of the Bemba country. The Bashilubemba are the holders and the owners of the Chieftainship including the Chitimukuluship even though they are not eligible for being paramount in themselves. Andrew Roberts in A History of the Bemba wrote:

The Senior Bakabilo are no mere servants of Chitimukulu but are themselves the hereditary holders of historic titles, some as old as the Chitimukuluship itself and they are in a real sense the source of chiefly legitimacy. First of all, they are the Senior Bakabilo of Chitimukulu, those who determine the most crucial issues, such as the royal succession. These men are known as Bashilubemba, the elders of Ulubemba and these are: Chimba, Chitikafula, Kapukuma, Katenda, Munuka and Nkolemambwe. (Roberts 1973:15)

The meetings of the council were presided over by the senior Chief of the district, the natural ruler of the locality, that is, Ituna: is presided over by Senior Chief Mwamba; Icinga: Senior Chief Nkula, Mporokoso, by Senior Chief Mumporokoso, Chikwanda by Senior Chief Chikwanda and Luwingu by Senior Chief Shimumbi. A local council had authority only over local affairs. But representatives of a number of councils constituted a general council of the Bemba country called Ilamfya which was presided over by Paramount Chief Chitimukulu, the Mwine Lubemba himself. Ilamfya was the biggest democratic unit of the Bemba people's democratic council at which all people who live in Bemba land are represented.

Irrespective of the level, deliberation was the most important feature of the traditional system of decision-making. Deliberations here have two methodological aims:

- to identify the differences of opinion

- to reconcile them out in search of consensus.

The reaching of consensus in the Bemba political system was a matter of principle and discredited the idea and practice of more difficult processes than decision by majority vote, yet they preferred the former to the latter because it ironically dealt with through 'free discussion' (Mutiso 1975:478). It is believed that the voting system subordinates the will of the minority to that of the majority in the matter of a given decision, by the simple act of voting. For example, in the matter of the Chimukulu succession, the matter was not left to the BanaMfumu (Royal Mothers), but Ba Shilumba took the centre stage to reach consensus, 'by seeking the goodwill of all members through sincere dialogue' (Wiredu 1996:175).

Representation under the Bemba political system involved two things: firstly, the representation of each lineage in 
council; secondly, the representation of each representative in the making of each decision. Both representations were secured through consensus. The implication of this is that the people have the right to representation having their consent factored into every decision, through their representatives. In other words, consensual political system as practised in traditional Bemba society recognised and observed the fundamental human right to be represented in any political council in which decisions are made on the people's behalf. This type of human right, right to decisional representation in government, is the hallmark of consensual democracy and arguably is conspicuously lacking in majoritarian democracy.

By majoritarian democracy, we mean a multiparty system of politics in which the party that wins an election in terms of numbers, and the most seats in parliament are normally entitled to form government. In such a set-up, 'the losing party or parties become opposition, singly or composedly' (Wiredu 1996:176). Under this majoritarian model of democracy, one still finds the minority representatives casting votes. But the point is that they will be overridden by the votes of the majority which in practice ignores even the wise expertise of the minority people. This means the right of the minority and of their constituencies to be represented in actual making of decisions is rendered nugatory. This makes the struggle for power to be fierce and confrontational. Thus rather than promoting consensus and cooperation, the multiparty system generates conflicts and disaffection.

This was highlighted by Paramount Chief Mpezeni of the Ngoni people of the Eastern Province of Zambia who 'asked President Rupiah Banda to tribally balance his cabinet because Ngonis are not represented' (The Post Newspaper, Zambia, Wed, 12th May 2010). He said:

I have no minister in Cabinet. It is just other chiefs from here Eastern Province who are enjoying; Lameck Mangani (Home Affairs Minister) and Dr. Kazonga (Local government and housing Minister) are Chewas from Chief Gawa Undi. Dora Siliya (Education Minister) and Peter Daka (Agriculture Minister) are Nsenga. Maxwell Mwale (Mines Minister) is Kunda. So what do I have? Nothing! Not even a Diplomat.

With the utterances of Paramount Chief Mpezeni, there was a demand in some quarters that tribal balancing needed not to be provincial balancing but rather needed to be about adequate representation. As such, His Majesty the Mpezeni was complaining that among the five cabinet ministers from the Eastern Province in Rupiah Banda's Movement for Mulitparty Democracy (MMD) cabinet, none of them were Ngonis. Without Ngonis in Cabinet, Mpezeni felt left out of national development. That intra-provincial tribal conflict was the greatest danger to Zambia's democracy and development, and to that effect it is our thesis that the consensus principle would be the right path to take cognisance of this problem.

It is argued that the alienation of the right of being represented can be perceived to be one of the most persistent causes of political instability in Africa due to the fact that most African political movements are biased towards one's tribal affiliation. It is a known fact that in Zambia, certain groups of people and tribes have found themselves consistently in the position of the minority both numerically and politically, and this means that they will consistently find themselves outside the corridors of power, for example, the political party with a candidate with the highest support of the Bemba-speaking people will always win an election. This situation has not only generated enmity in the society, but has also culminated into a condition where the fundamental human rights of decisional representation of the category of the people are permanently denied with impunity.

As a rescue to the consequences of the majoritarian (multiparty) democracy in Zambia, we argue that the alternative is not the return to the concept of Kenneth Kaunda's one-party system which Zambia experienced from 1972 to 1991, as that would be worse to human promotion and sustenance of the social order. The plausible democratic alternative for Zambia is a non-party state, which is built on the culture of consensus in contemporary Zambian-African society. A non-party state model of democracy by consensus:

\footnotetext{
$\ldots$ is one in which parties are not the basis of power. People can form political associations to propagate their political ideas and help to elect representatives to parliament. But an association having the most elected members will not therefore be the governing group. Every representative will be in government in his personal as a representative of the people, rather than in associational capacity. (Wiredu 1980:179)
}

In the areas of filling to legislative and executive positions, it is proposed that the elected representatives may elect a leader and charge them with the responsibility of forming an administration reflecting the consensus principle' (Wiredu 1980:180-189). Under this democratic arrangement, the merit of ideas is the driving force, which promotes not just formal representation but substantive representation of the whole people of the spirit of 'democracy for all' (Mutiso 1975:478). Hence, the possibility of being marginalised in the process of the decision-making is unlikely.

It is further argued that this type of political arrangement will make it possible for all concerned to participate in power and it has the benefit of reducing the adversarial political practices and post-electoral conflict that is the characteristic of the multiparty system in Zambia. This non-party consensual model of democratic representational government is an African alternative to western multi-party democracy; is an antidote to unending crisis of fundamental human rights abuse in Africa' (Mutiso 1975:179). I envisage that in this political system, the citizen's right to representation will be respected under this political arrangement where governments are not formed by parties but by the consensus of the elected representatives. Based on the framework that having a dispensation under which a government is formed not by parties but by the consensus of elected representatives who form the electoral college. In this way, government becomes a kind of coalition - a coalition not as a common acceptation of parties but a coalition of citizens. By this proposal, we are not 
against the formation of political associations to propagate certain preferred ideologies, but in councils of state, affiliation with any association will not necessarily determine the chances for a position of responsibility.

\section{Distinctive marks of the Zambian context}

By distinctive marks of the Zambian context, I mean the unique qualities that define the Zambian people's way of life both the general identity of the Zambian people and the constitutional provisions of the country which have influence in their political governance of the country. These distinctive marks are what define the general practice of the African Zambians level of engagement in public life.

\section{The Zambian Christian nationhood}

Zambia is constitutionally a Christian nation whose Christian nationhood emanates from a presidential decree. The declaration of Zambia as a Christian national was made by Fredrick Chiluba, the second president of the Republic of Zambia on 29 December 1991. In June 1996, an amendment to the Constitution of Zambia Act of 1991 to include the Zambian Christian nation declaration was affected and 'from that moment, Zambia became officially, the Christian Nation' (Muwowo 2010). History informs us that all the presidents of Zambia from independence had been in one way or the other 'fruits of missionary work' (Muwowo 2010). Therefore it's not a surprise that the path they followed to lead the country, could only be feasible within the framework of Christian ethics and values. This owes to the fact that Christianity was the basis for their engagement with the liberation struggle which later gave birth to Zambia's independence on 24 October 1964. Kenneth Kaunda (1964-1991), Fredrick Chiluba (1991-2001), Levy Mwanawasa (2001-2008), Muwowo (2010), Rupiah Banda (2008-2011) and Michael Sata (2011-14) were all products of the Christian missionary enterprise which evangelised the gospel from late 19th century and established mission centres across Southern Rhodesia which later became Zambia at independence. Kenneth Kaunda in particular was a son of a missionary of the Church of Scotland from Livingstonia Mission in modernday Malawi. Fredrick Chiluba and levy Mwanawasa grew under missionary influence and inspiration in the Copperbelt Province of Zambia. Rupiah Banda was influenced by the Anglican communion of the Church of England and Michael Sata was a product of the Roman Catholic missionaries under whom he attempted to train as a priest. It is worth noting that all presidents of Zambia in the past and present have been a lynch pin in the development and propagation of the Christian values within the Zambian governance system.

Against the Christian missionary influence to politics in Zambia, when Dr. Fredrick Chiluba was elected president of the Republic of Zambia in October 1991 with Levy Mwanawasa as his vice-president, 'he declared on 29th December, 1991, that Zambia was a Christian nation in covenant with God' (Muwowo 2010). He made the Christian nation declaration on behalf of Zambia as follows:
On behalf of the nation, I have now entered into a covenant with the living God and therefore, I want to make the following declaration. I say here today that I submit myself as President to the Lordship of Jesus Christ. I likewise submit the government and the entire nation of Zambia to the Lordship of Jesus Christ. I further declare that Zambia is a Christian nation that will seek to be governed by the righteous principles of the word of God. Righteousness and justice must prevail in all levels of authority and we shall see the righteousness of God exalting Zambia. My fellow Zambians let this message reach all civil servants in all government departments. The time of corruption and bribery is over. For too long these wicked practices have been destroying and tearing down the nation. Now the hour has come for our building up. The hour has come for our stability. Proverbs 29:4 declares 'Who is greedy for bribes tears down a nation, but by justice a king gives the country stability'. (Times of Zambia 20.12.1991)

The president's actions caused a rift on how a nation could interpret the role of the church in determining the form of government since the Christian values were to be a yard stick of government operations. Of course it definitely calls for a Christian form of government in which injustice, tribalism and nepotism are overcome. However, instead of the declarations role to bring the Zambia people together, it:

caused a major rift in the church-state relations and also among church organisations. Those who supported the declaration saw themselves as allies of the political administration and the true 'Christians'. Those who were apprehensive were perceived as pseudo-Christians and against the political administration. (Muwowo 2010)

Such an encounter introduced a new context of politics in Zambia in which apart from the dominant vices that separated the people of Zambia, the church and church affiliation was added as one of the principalities. In the context of such new challenges, 'the Christians who supported the Christian nation declaration saw it as a challenge to Christianise politics' (Muwowo 2010). One Pentecostal pastor of the Pentecostal assemblies of God was quoted as having said, ' $70 \%-80 \%$ of the Zambian 8.5 million was Christians'. Therefore, 'there was nothing wrong with declaring the country Christian'. The inference here was that since Zambia's population was mostly Christian then it could implement Christian principles and laws in its governance (Muwowo 2010).

After an engagement with different sections of the people, in Zambia from the grassroots, 'during the amendment to the constitution, parliament adopted a clause to enshrine the Zambia Christian nation declaration' (Muwowo 2010). One of the positive things about the clause is that it affirmed the Christian nation declaration, but it also acknowledged the importance not to alienate people's choice to religion. It emphasised that the Christian nation declaration was only meant to give a religious identity of Zambia as Christian. The amendment clause reads as follows:

We, the people of Zambia by our representative, assembled in our parliament, having solemnly resolved to maintain Zambia as a Sovereign Democratic Republic; Determined to uphold and exercise our inherent and inviolable right as a people to decide, appoint and proclaim the means and style to Govern ourselves; 
Recognize the equal worth of men and women in their rights to participate, and freely determine, and build a political, economic and social system of their own free choice; Pledge to ourselves that we shall ensure that the state shall respect the rights and dignity of the human family, uphold the law of the State and conduct the affairs of the state in such a manner as to preserve, develop, and utilize its resources for this and future generations; Declare the republic a Christian Nation while upholding the right of every person to enjoy that person's freedom of conscience or religion; Resolve to uphold the values of democracy, transparency, accountability and good governance; and further resolve that Zambia shall ever remain a unitary, indivisible, and multi-party and democratic sovereign state. Do hereby enact and give to ourselves this constitution. (The Constitution of Zambia amendment Act No. 18 of 1996)

This act which was placed in the preamble of the national constitution 'caused more mixed feelings in Zambia and abroad as by virtue of including it in the Zambian constitution became law and therefore binding' (Muwowo 2010). From that moment, it was viewed that the government had brought the church into politics of religious separation thus adding more division to those that were done at regional and tribal levels.

It is worth noting that the declaration itself singled out the Christian religion that in itself causes an understanding of the core principles of the country. Since in a democratic country, every citizen has freedom of choice and freedom of conscience as outlined in the Zambian constitution Articles 11, 19 and 23, which one way or the other guarantee everybody in Zambia the enjoyment of fundamental human rights and the freedom of thought and religion (Constitution of Zambia 1991), only a consensus form of governance could reconcile the different sections of people in order to achieve an authentic democratic governance.

\section{Zambia: An African nation}

Zambia as a nation belongs to the family of the African continent and its people whose culture and world views are diverse but they all rest on similar interests. The African people are a unique species of the creation of God. John S. Pobee defines the African people as a 'homo Afrikanus', a 'multi- headed hydra displaying varieties not only vis-a-vis the non-African but also vis-a- vis other species of the homo Afrikanus' (1979:43). This definition implies that those who are called Africans living in and within the African continent they remain one people in body, mind and soul with similar interests and aspirations despite being found in particular groups or places in terms of country, social class, tribe or clan. It is worth noting that 'ecological factors have shaped diverse physical types of the African man on the continent with different languages and cultures' (Pobee 1979:43-52); yet these factors do not uproot the reality of the beliefs and unique common cultural genes found in all of them. In this case, we envisage that a Zambian-African would display some similar African experiences that an African from another country would. These experiences cut across all dimensions of an African person, be it 'political, economic and social' (Chuba 2011).
The composition of the African people shows that there are:

nearly fifty nations in the continent with different constitutions and varying histories [...] there are several linguistic groups which can be grouped into clusters, according to similarities in linguistic structures of their mother tongue. (Mugambi 1989)

When John S. Pobee (1979) gives a perspective of an African as, 'a homo Afrikanus' and defines her as 'a multi-headed hydra delaying varieties not only vis-a-vis the non-African but also vis- $a$ - vis, other species of the homo Afrikanus'. He acknowledges the fact that an African person has a plural disposition when it comes to their practical lifestyle. No wonder in the history of the world, only the African people have varieties of languages more than any other people in the world. Africa has 'at least four major stocks of languages: Afro-asiatic, Niger-Congo, Sudanic and click. There are at least three cultural groups: Caucasoids, Negroids and Hamites' (Pobee 1979). These diversities demonstrate the metaphor of a 'homo Afrikanus as a multi-headed hydra and African cultures legion' (Pobee 1979). However, the recognition of these diversities cannot be used to overlook the reality of the aspiration for a commonality in the African experience and heritage which in essence defines who an African is. It is true that 'certain sociological and cultural factors are peculiar' (Mugambi 1989) to Africa and African identity and therefore, we have a ground to argue for an African Theology that can speak to various situations to Africans let alone to its democratic model of governance. For example, 'kinship as a social institution among the matrilineal society has continued to hold an important place in decision making in Africa' (Mugambi 1989) as well as the common political destiny of African countries in which, 'Africa has the most world resources but its people remain poorest and oppressed' (Mugambi 1989). It is against this back ground that Africa can be understood as 'a homogenous unity comparable and contrastable with other continents (Mugambi 1989) in the world.

\section{Politics of tribe and ethnicity in Zambia}

The third distinctive mark of the Zambian context are politics of tribe and ethnicity. It is worth noting that at independence in 1964 Zambia's first president Dr. Kenneth Kaunda 'naively thought that Zambia had entered a new era of post-tribal politics' (Munshya 2013). He had managed to convince the Litunga, the King of the Lozi tribe in the present-day Western Province, to have 'Barotseland proceed to independence with the rest of Zambia as one nation' (Larmer 2011). He had also assisted in supporting the London missionary Society, the Church of Scotland, the district of the Methodist Church of Britain, the Paris Evangelical Church among other protestant missionary societies doing mission in Southern Rhodesia to negotiate and form a united church. The negotiations were successful which led to the union and formation of the United Church of Zambia which was inaugurated on 16 January 1965 , barely 4 months into power of the independent Zambia. President Kenneth Kaunda was the guest of honour at the inauguration service which was held at Mindolo Ecumenical Foundation in Kitwe. 
Kaunda's United National Independence Party (UNIP) was the principal brand of unity. The national motto was quickly hoisted to be 'One Zambia One Nation' (Larmer 2011) to depict the unity that had been attained leading to the independence of Zambia from Britain. For Kaunda, he had achieved his dream; a united Zambia had been formed but little did he know that 'the unity that bound the country together to attain independence to overcome colonialism was a common hatred of colonial domination and the imperial regime, not Christianity, or a common love for each other' (Muwowo 2013). As such barely three years into power, 'Kaunda realised that the Zambian tribes were not as united as he had thought' (Munshya 2013). It was evidenced during the first post-independence UNIP convention in 1968 which saw a very bitter tribal fight. 'The Bemba - Tonga pact had at the UNIP convention bitterly defeated the Lozi - Nyanja alliance' (Munshya 2013). Tribe and ethnic campaigns characterised the entire system, and for the first time unity, peace and harmony, which were enjoyed prior to the introduction of the multisystem, were instantly lost. To the consternation of Kaunda and Kamanga, on tribal pecuniary advantage 'Simon Kapwepwe was elected UNIP's vicePresident an easterner had been defeated' (Munshya 2013). In fact, it was during this time, that some UNIP members started doubting Kaunda's loyalty to the Bemba tribe 'since he had Malawian parentage' (Larmer 2011). The era of tribal politics engulfed the nation for the first time, a sign that something had gone wrong in the political arena.

To overcome this, Kaunda retraced and reemphasised his loyalty as 'a Bemba subject of Chief Nkula in Chinsali' (Munshya 2013). He also made a point to try and persuade Kapwepwe to step aside since two Bembas could not possibly hold two top positions in both UNIP and the government. Kapwepwe reluctantly obliged and 'Kaunda quickly brought in Mainza Chona, a Southerner to replace Kapwepwe' (Larmer 2011). But this deeply displeased Kapwepwe and several other Bemba hegemonists, who later proceeded to found the 'UPP, a party mainly popular in Luapula and Copperbelt provinces' (Munshya 2013).

The inauguration of a one-party (UNIP) state by Kaunda in 1972 was made in order to arrest 'the trends perceived towards ethnic and provincial parochialism' (Larmer 2011). The UNIP government under Kaunda believed that it had succeeded in containing 'ethnic and tribal parochialism by introducing a one party state through the Choma declaration' (Larmer 2011).

Throughout his political career, Kaunda took account of the prevalence of ethnic and tribal allegiances through what he called 'tribal balancing'; thus he allocated political portfolios according to the relative strengths of tribal and ethnic loyalties. In this new arrangement, he made sure that the provinces were well represented in government. It was so intentional that you could actually predict who would be in cabinet and who would not. However, the position of Prime Minister was almost exclusively reserved for Barotseland. 'Out of six Premiers, from 1973 to 1991, four were Lozis and the other two were Tonga' (Munshya 2013). This was Kenneth
Kaunda's tribal balancing at its best. It was mostly dictated by province more than it was dictated by specific tribes.

When Chiluba, the second president of Zambia, came into power in 1991, 'the intentional and deliberate tribal balancing was effectively overruled' (Munshya 2013). Chiluba would appoint people on what he publicly called 'merit'. However, 'it still remains to be answered why under Chiluba almost all parastatal chiefs had Bemba names such as - Chungu, Musenge, Musonda, Mwansa, etc.' (Munshya 2013) which actually means that appointment on merit may have meant tribal merit as well. But even if this is the reality with Chiluba, he was never accused of playing tribal politics because predominantly the Bemba have an upper hand in the running of Zambia. However, if it is a minority tribe doing the same thing, some vocal quarters could condemn the practice without delays and throw the country into unnecessary debates. This assumption among some Zambians that only non-Bembaspeaking people are more capable of tribalism is erroneous. Comparing all the former presidents on tribal appointments Chiluba appointed more people in his cabinet and parastatal companies that were Bemba more than any other president, and yet the tribalistic label has not stuck with Chiluba.

However, when leaving power in 2001 Chiluba favoured a minority tribe to take over. "This honour obviously fell on Mwanawasa - of both Lamba and Lenje heritage' (Munshya 2013). Even without objective evidence, Mwanawasa was quickly accused of appointing a family tree in his cabinet. But once objectively assessed one would see that Mwanawasa's cabinet was more tribally balanced than Chiluba's at any given time. Mwanawasa also brought in some tribal diversity in parastatal companies. However, 'when he appointed Sisala as ZESCO Managing Director, more tribalistic accusations were levelled against him' (Munshya 2013). This again plays to our thesis that several Zambians believe, erroneously, that only non-Bembas are more capable of tribalism. Mwanawasa tried to please the Bembas by appointing them to the vicepresidency just to win Bembas' support. He only revolted when he lost the Bemba vote in 2006 and turned to an easterner.

However, as alluded to above, under Rupiah Banda, fourth president of Zambia the issue of tribalism had taken on a new shape all together. In the past, it was sufficient that provinces should be represented in the cabinet. As such, 'Eastern Province would not normally complain if a Chewa, Tumbuka, Ngoni, or Kunda is appointed to Cabinet' (Munshya 2013). But chiefs demand that their people should be represented in the cabinet. His Majesty the Mpezeni, Paramount Chief of the Ngoni people of the Eastern Province, complained that among the five cabinet ministers from the Eastern Province in President Banda's cabinet, 'none of them are Ngonis'. (Munshya 2013). Without Ngonis in Cabinet, Mpezeni feels left out of national development. This intra-provincial tribal conflict remains the greatest danger to Zambia's politics. Similarly in Luapula Province, there were complaints that the MMD had started to sideline Southern Luapulans (mostly Ushis) in preference of the Northern Luapulans (Lundas, 
Bwiles, etc.). Northern Province is even more dynamic. Hon Geoffrey Bwalya Mwamba said while campaigning that 'Northern Province belonged to Bembas, ignoring its multiethnicity' (Munshya 2013).

The challenge for Zambians political context is that 'One Zambia One Nation' is on crossroads as the country has 73 different ethnic groups; yet tribal and ethnic politics continue to eat the little peace that is there. If the provinces stop intraprovince tribalism and begin to look at themselves as one people, only then can Zambia progress. But the challenge remains, that is, the model of democracy which is able to facilitate the unity of tribes and ethnic groups, otherwise if we continued on this path, we may just end up being one Zambia and no nation.

By looking at the about distinctive marks, it is worth noting that the context of Zambia is peculiar awing to the three basic distinctive marks that inform the setting in which politics are done. This particular context leads us towards an attempt to formulate an ethical-theological framework for a non-party democracy by consensus that comprehensively responds to Zambia's peculiar situation. Here now lies our point of departure.

\section{An ethical-theological framework}

Governance is a gift from God and therefore our engagement with it should take cognisant of God's principles as a common denominator in order to respond to the challenges of democratic engagement. However, if the concept of democracy needs to be a way to good governance in every nation, then it must be a dynamic one. It must surely be informed by 'incarnation nature' (Bevans 2009), a character that would enable it to emerge out of the culture of the people in the African context as a determination for political engagement and practice. The character of incarnation culminates from the model of God at the time he decided to save the world. He took an initiative that would attract a response that would be natural within the traditions and the culture of the people. When John's gospel records 'God loved the world' (Jn 3:16), he expressed it to a degree that out of that love, 'God wanted to share God's self with men and women and invite them into the means of a life giving relationship with the Godhead' (Bevans 2009). The basic interpretation of this means that the nature of sharing, be it power, food, expression, love and togetherness must all lead to life-giving concept with one another and with the company of God. But this ideology presupposes that 'if God was going to do this, the means of communication would have to be in a way that human beings could fully grasp a way that expressed the reality of what this invitation into friendship and relationship was all about' (Bevans 2009). As expressed by John, 'God became flesh' (Jn 1:14) and his expression was not generally but particularly owing to the fact that there cannot be a concept that could be universal even if the basic goals are the same. In this action, 'God became flesh, a human being, in the person of Jesus, a Jew, son of Mary, a male' (Bevans 2009)
The implication of this is that 'God became flesh in a human person of such and such height, with particular colour; heir with particular personality treats etc.' (Bevans 2009). In this way, he was to be raised with a particular people and out of them emerges salvation for all. In a single sentence, the process of incantation as a practical matrix of God is a process of becoming particular and in and through the particular, the divinity could become visible and in some way [...] become graspable and intelligible' (Bevans 2009). This matrix follows naturally that the message of God, 'if it is to touch people, we have somehow ourselves to continue the incarnation process. This presupposes that through African Christians and theologians, God becomes '... African, Black or brown, poor or sophisticated. Christians must be able to speak to inhabitants of the 21st century' (Bevans 2009) Africans about the reality of God's nature who was born into the world of all unique cultures and races. This includes God as a participant in both political and social lives of the people of Africa. It arises from this particular dimension that Christianity, 'if it is to be factual to its deepest roots and to its most basic insight' (Bevans 2009), must continue God's incarnation in Jesus by becoming African people with African forms of political practice which are fully informed by the cultural practices of the African people. Rev Padilla when speaking about doing a contextual mission in any part of the world had this to say:

The incarnation makes clear God's approach to the revelation of himself and of his purposes. God does not shout his message from the heavens; God becomes present as a man, among men. The climate of God's revelation is Emmanuel and Emmanuel is Jesus, a first century Jew, the incarnation unmistakable demonstrates God's intention to make himself known from within the human situation. Because the very native of the gospel, we know this gospel only as a message contextualised in culture. (Padilla 1979)

In this conception of theology, we argue a situation where a true African democracy should situate itself in a position whereby it is challenged by the incarnation nature of the gospel and Christianity if indeed it is to be meaningful in African states and bring about harmony to God's people being governed by foreign ideology. African Christian Theology has to be understood in this way.

The second aspect of the incarnation nature of Christianity that challenges imperial democracy implanted in Africa is the sacramental nature of Christian reality of the doctrine of incarnation which 'proclaims that God is revealed not primarily in ideas but rather in concrete reality' (Bevans 2009). The real encounter of Jesus is in the flesh and as such 'we encounter God most fully' (Bevans 2009) because he came to be born among humanity. Thus, the 'sacrament of the encounter with God' (Schillebeeckx 1963). The nature of God's encounter with human cultures 'continues to take place in our world through concrete things. God is encountered in the remembering of the Christian community gathered around the table on which are bread and wine, in oil given for healing or as a sign of the vocation, in gestures of forgiveness or commissioning' (Bevans 2009). These practices 
do not have meaning in themselves but they are consecrated ritual moments that point 'beyond themselves to the whole of life' (Bevans 2009). They proclaim 'deep faith in the fact that the world and its inhabitants and their deeds and events are holy and that at any time and in any place and through any person, these persons and things can become transparent and reveal their creator as actively and lovingly present to creation' (Rahner 1961). Our argument here is that 'if the ordinary things of life are so transparent in God's presence' (Bevans 2009), we can therefore speak of cultural prospects, human experience and events in history as truly 'sacramental and so revelatory' (Bevans 2009). This could be expressed in the way people live their lives, govern themselves and do things in a unique way. In this way, if Christianity has to be true to itself, "the real dynamic of Christianity's selfunderstanding must be 'unpacked' of its sacredness" (Mugambi 1989). It is worth noting that in Africa, the sacramental nature of life is a real experience and is expressed through the rights of passage at "birth, puberty, marriage and death" (Mugambi 1989). Talk of democracy and the form of government in Africa, should therefore be part of the sacramental project of the African people in which the divinity of God (gods) are expressed and appeased.

The third dimension of Christianity's conceptualisation as a theological discourse for the transformation of African democracy arises from a 'shift in the understanding nature of the dimension of revelation' (Bevans 2009) as being a plausible factor in the determination of an African theological nature of democracy that is rooted in the African world view of governance. In this conceptualisation, revelation is conceived as the offer of God's very self to men and women by means of concrete actions and symbols in history and in individuals daily life (Bevans 2009). The implication of this for African Theology presupposes that the revelation should be understood with the perimeters of 'God's self-communication to men and women: the giver as such is the gift and the person to whom the gift is given is thus called to his or her personal fulfilment' (Rahner 1978). Culminating from this understanding, faith was therefore understood as a personal response as well as a self-gift of a person to God (Bevans 2009). This conception dispels all manner of dimensions that come with imposition and forcing nature responding to an action is coupled with willingness which shall be expressed naturally from one's understanding of things.

Where a gift cannot be considered as valuable one, Stephen Bevan suggests that 'God in offering God's self would certainly take time and effort to make that offer relevant' (Bevans 2009). This calls for the church in Africa, who represent and continue God's work in the world to do no less than God like. We are to be faithful to our basic vocation of preaching the true nature of God in all spheres of life including political and social economic civil among others. This interpersonal conception of revelation points to the necessity of an African Theology that takes serious and interprets the actual democracy in African society in which men and women experience God for their daily African lifestyle.
The fourth dynamic matrix of African Theology of Democracy is the Christian's conceptualisation of the 'catholicity of the Church' (Bevans 2009) expressed in the apostles creed. The concept of catholicity implies the very nature of what the church should try to be in the world and a universal entity whose mission, is aimed at the whole people of God. According to the dictionary of Christianity (2000) the word catholic comes from two Greek words, krata and holos and points to the all-embracing, all inclusive, all accepting nature of 'Christianity' (Bevans 2009). This understanding of Christian faith presupposes the oneness of the people regardless of their ethnicity, tribe, race, region, clan and religion. To be catholic in the meaning of the word means being 'receptive to the sound achievements of every race and culture' (Bevans 2009). This is what it means when looking at the African traditional cultures, regardless of the diversities 'Catholicism pays respect not to the mind alone nor only to the will and the emotions, but to all levels and aspects of human existence' (Dulles 1988).

Implanted in our African society, the catholic phenomenon talks translate into the universality of all persons and therefore determine an approach that 'champions and preserves the local and particular rather than a band uniformity' (Bevans 2009). The practical disposition of Christianity as a primary entity for this conceptualisation is endowed with 'a dynamic that moves toward unity through a rich diversity, through conversation and even argument among people of particular personal, cultural and historical experience' (Bevans 2009). This is where the African Theology of Democracy emerges from. The universality of the church presupposes the participation of all people because the actual essence is the 'full grown humanity of Christ which requires all the Christian generations, just as it embodies all the cultural variety that six continents can bring' (Bevans 2009).

It is worth noting that the diversity of cultures and ethnicity within this complexity requires a complete dialogue to take place and a channel of achieving goals whereby 'all persons and cultural groups have to dig deep into their own social situation, personal experience and cultural existence to see how these interact with God's offer of friendship and relationship in Jesus Christ. Thus the dynamic of catholicity calls for a contextual approach to theology by its very nature' (Bevans 2009). This conceptualisation challenges African Theology with a model of engaging with social issues of people of plurality.

The last dynamic matrix of Christianity that would inform African Theology of Democracy lies in the 'Doctrine that is at the heart of Christianity: the Trinity' (Bevans 2009). The Trinitarian thought implies that concept of togetherness and oneness in the practice of every activity and for African Theology of Democracy. It is worth noting that the 'contemporary understandings of God as Trinity' (Bevans 2009),speak of God as a "dynamic, relational community of persons, whose very nature is to be present and active in the world, calling it and persuading it toward the fullness of 
relationship that Christian tradition calls salvation" (Bevans 2009). It is through God's works for salvation in the midst of human contexts, such as cultures, events, suffering, joys, governments and so on, that God manifests himself in. It awes to this very fact that the teaching about 'Gods dialogical nature is the source for the church's catholicity and theology's need to embrace and wrestle with the concrete' (Bevans 2009).

African Christian Theology has a lot to offer to the world of democracy to Africa because 'Christian faith in God as Trinity opens up a vista of Gods marks in the works, events, in peoples experience and cultures, in natural worlds' (Bevans 2009). African theologians here need to do theology of democracy and guide the Africa project because God is present and acts particularly.

\section{Conclusion}

Future considerations regarding the development of democracy in Zambia should, first and foremost, be multifaceted. I have comprehensively argued through my methodology that 'a homo Afrikanus is a multiheaded hydra' (Pobee 1979:43-52) whose disposition is plural in both character and action. For this reason, the major task that is ideal for Zambia should be such that any model to be considered must be adaptable to the unique nature of the countries traditional and cultural value systems if indeed positive results are to be attained in terms of governance. A reality that 'the vestiges of colonialism such as authoritarianism and ethnic, religious, and class cleavages are still quite entrenched in many locales' (Bradley 2005:414) possesses a challenge that democratic models have to be able to accommodate and account for such realities through an authentic consensus practice of democracy.

There are many types of accommodations which can be made to combat the realities of the chaotic Zambian multiparty governance system which has led the country into massive tribalism and regional politics. For example, genuine representation of all ethnic and religious groups in legislatures might be a starting point. It is a fact that our Zambian multiparty political system is biased towards certain tribes, who determine the direction on behalf of people who they do not physically represent. And even though bonafide representation might mean increased legislative incrementalism or gridlock, such representation could help quell civil unrest, especially in the Western Province where the demand for service delivery has led to massive demonstrations for the restoration of the 'Barotse Agreement of 1964 '. In order for the Lozi tribe to enjoy a lion's share of the national cake, this and many actions have, by and large, promoted tribal and regional politics in Zambia as a result of multiparty democracy principles which are really alien to the African concept of doing politics.

We propose that Western and non-Western models of democracy should be reconciled to enhance a tolerant political governance system based on a Zambian African context. First and foremost, Western democratic leaders and their foreign policies must take seriously that Zambia among African countries is at a different stage of democratisation; thus it needs to be treated differently based on its contextual situation. Of course even the constitution provision which declares Zambia as the Christian nation, makes it to have a different political context which should be handled uniquely if indeed a way forward is to be established.

In the light of the foregoing flaws and antimonies of the notion of multiparty democracy as a foreign construct, the apparent conclusion is that it has helped to open a way into the discovery of human rights, its realisation and promotion in the 21st-century Africa. While this article is not totally discrediting multipartism in Zambia, the discovery of the decisional representation, rooted in ancient African traditions of the Bemba and which currently is lacking in both the Universal Declaration of Human Rights and the African Charter on Human and Peoples Rights, makes good reading. The stance of the article is that our exploration of the necessary interconnectedness of consensual democracy and the right to decisional representation should go hand in hand.

It goes without question that given the string of problems, which the notion of multiparty democracy is fraught with, it stifles the possibility of an alternative democracy in Zambia based on the Bemba model we have comprehensively overhauled, which will promote better human rights to decisional representation in contemporary Zambian politics. Future research into the Bemba governance can explore further how every citizen of Zambia can be made to participate fully in the development of the country through decisional representation.

Shortcomings in the multiparty democracy open away into this possibility of an alternative democratic theory. This is important in order to provide a sound theoretical foundation of democracy that will give credence to, and foster the respect, observance and promotion of the right to decisional representation in contemporary Zambian politics. While we have made our contribution to indigenous African understanding of human rights and democracy, the challenge before contemporary African theologians and philosophers is to continue and further expand the discourse beyond this framework especially in the area of rights to representations in African governments. This will be done with no other aim than to reflect on how to emerge a viable, strong and better model of democracy for the promotion of the right to decisional representation in 21st-century Zambian politics.

\section{Acknowledgements}

I want to thank my study leader and mentor, Prof. Dr Vuyani Vellem, for scholarly inspiration, guidance and critical instructions throughout my research project.

\section{Competing interests}

The author declares that he has no financial or personal relationships which may have inappropriately influenced him in writing this article. 


\section{Authors' contributions}

V.V. was the study leader of the research project under the title Multipartism and the Matrilineal governance system of the Bemba speaking people of Zambia: An African theological perspective' which produced the results reflected in this article.

\section{References}

Ake, C., 1981, A political economy of Africa, Longman, London.

Ake, C., 1991, 'Rethinking African democracy', Project MUSE Scholarly Journals Vol. 2(1), 32-44. https://muse.jhu.edu/article/225609/pdf

Ake, C., 1993, 'The unique case of African democracy', International Affairs 69, 239-244. http://dx.doi.org/10.2307/2621592

Anyangwe, C., 1996, The Christian Nation Declaration: A legal perspective, University of Zambia Press, Lusaka, Zambia.

Austin, G., 2000, 'Markets, democracy, and African growth: Liberalism and AfroPessimism Reconsidered', The Round Table 357, 543-555. http://dx.doi. org/10.1080/003585300225179

Barnard, A., 1992, Hunters and Herderss of Southern Africa: A comparative ethnography of the Khoisan peoples, Cambridge University, Cambridge.

Basedau, M., 2007, 'Do party systems matter for democracy? A comparative study of 28 Sub-Saharan countries', in Matthias Basedau, Erdmann \& Mehler, pp. 105-141 London.

Bates, R.H., 1981, Markets in tropical Africa: The political basis of agricultural policies, University of California Press, Berkeley, CA.

Beetham, D., 1995, What is democracy? Eighty questions and answers, UNESCO, Paris

Bendiako, K., 1997, Africa in World Christianity in the 21st Century: A vision of the African future, Akropong-Akuapm, Ghana.

Bevans, S.B., 2009, Models of contextual theology, Orbis Books, New York.

Bogaards, M., 2007, Electoral systems, party Systems and Ethnicity in Africa, Erdmann \& Mehler pp. 169-193.

Bradley, M.T., 2005, "'The other" precursory African conceptions of emocracy', International Studies Review 7(3), 407-431. http://dx.doi.org/10.1111/j.1468-2486. 2005.00507.x

Bratton, P.M., 2000, Attitudes to democracy and Markets in Nigeria. Afrobaromete paper no.3 Michigan State University Working papers on Political Reform in Africa. Afrobarometer Network.

Brelsford, V.W., 1965, The tribes of Zambia. Government Printers, Lusaka.

Bujo, B., 1992, African theology in its social context, Orbis Books, New York.

Busia, K., 1967, Africa in search of democracy, Routledge \& Kegan Paul, London.

Carothers, T., 2002, 'The end of the transition praradigmn', Journal of Democracy 13(1), 5-21. http://dx.doi.org/10.1353/jod.2002.0003

Chazan, D.R., 1987, The precarious balance, Westview Press, Boulder, CO

Chazan, N., 1994, Civil Society and the Sate in Africa, Lynne Rienner Publishers, Boulder, CO.

Chiluba, F.T.J., 1991, Speech by the Pillar, State House Press, Zambia.

Chuba, B., 2011, God of our fathers and mothers is our God: African Christian theology in practice, Mission Press, Ndola.

Claude, A., 1996, Democracy and development in Africa, Bookings Institution, Washington, DC

Cohen, J., 1994, Civil society and political theory, Verso, London.

Coquery-Vidrovitch, C., 1997, African women: Modern history, Westview Press, Boulder, CO.

Dahl, R.A., 1989, Democracy and its critics, Yale University Press, New Haven, CT De Gruchy, J.W., 1979, The Church struggle in South Africa, Eerdmans, Grand Rapids, MI. Diamond, L., 1992, 'The second liberation', Africa Report 37(6), 38-42.

Diamond, L., 1998, Class ethnicity and democracy in Nigeria: The failure of the first republic, Macmillan Press, London.

Dorman, S.R., 2002, "'Rocking the boat?" Church NGOs and democratization in Zimbabwe', African Affairs 100, 75-92. http://dx.doi.org/10.1093/afraf/101.402.75

Dulles,A., 1988, The Reshaping of Catholicism:Current challenges in Theology of the Church, p 71. Harper press. San Francisco.

Evans-Pritchard \& Fortes, M, 1940, African political systems, Oxford University Press, London.

Fatton, R., 1991, 'Democracy and civil society in Africa', Mediterranean Quarterly 2(4), 84-95.

Fayemi, A.K., 2010, 'A critique of consensual democracy and human rights in Kwasi Weredu's Philosophy', Lumina 21, 1.

Gina, M.K., 2001, 'Party system institutionalization in 30 African countries', Party Politics 11(4), 437-468.

Gordon, F.D. \& Barkan, J.D., 1998, 'Democracy in Africa: No time to forsake it', Foreign Affairs 77(4), 107-111. http://dx.doi.org/10.2307/20048971
Gruchy, J.W., 1995, Christianity and democracy: A theology for a just World Order, Cambridge University Press, Cambridge.

Habermas, Faktizität und Geltung. Suhrkamp, 1992, English translation: Between facts and norms, Massachusetts: MIT Press, 1996.

Hameso, S.Y., 2002, 'Issues and Dilemas of Multiparty Demomocracy in Africa', West Africa Review 3(2), 1-32.

Harrison, G., 2002, 'Traditional power and its absence in Mecufi, Mozambique', Journal of Contemporary African Studies 20(1), 107-130. http://dx.doi. org/10.1080/02589000120104071

Haynes, J., 2001, “'Limited” democracy in Ghana and Uganda: What most important to international actors of stability or political freedom?' Journal of Contemporary Studies 19(2), 183-204. http://dx.doi.org/10.1080/02589000120066452

Herbst, H.B., 1996, 'The relationship between political and economic Reform in Africa', Comparative Politics 29(1), 23-42. http://dx.doi.org/10.2307/422181

Herneit-Sievers, A., 1998, "Igbo "traditional Rulers": Chieftaincy and the State in Southeastern Nigeria', Africa Spectrum 33, 57-79.

Huntington, S.P., 1984, 'Will more countries become democratic?', Political Science Quarterly 99, 203-235. http://dx.doi.org/10.2307/2150402

Ihonvbere, I.M., 1998, Multiparty democracy and political change. Constraints to democratization, Ashgate Publishing Ltd, Hants.

Joseph, R., 1987, 'Democratization in Africa after 1989: Comparative theoretical perspectives', ComparativePolitics 29(3),363-383. http://dx.doi.org/10.2307/422126

Kaphagawani, D.N., 1993, 'Democratic practice in Africa: Some arguments', Quest III(2), 71-79.

Karl, P.C., 1991, 'What democracy is.....And is not', Journal of Democracy 2(3), 75-88. http://dx.doi.org/10.1353/jod.1991.0033

Kasfir, N., 1998, 'No- party democracy in Uganda', Journal of Democracy . Volume 9 , Number 2. pp. 49-63. https://muse.jhu.edu/article/16882

Kaunda, K.D., 1962, Zambia shall be free, Heinemann, Sussex. UK.

Keller, E., 1995, 'Liberalization, democratization, and democracy in Africa. Comparative perspectives', Africa Insight 25(4), 224-230.

Kiros, T. (ed.), 2001, Explorations in African political thought, Routledge, New York.

Kiros, T. (ed.), 2001, Explorations in African political thought: Identity, community, ethics. Routledge. London.

Kuperus, T., 1999, 'Building democracy: An examination of religious associations in South Africa and Zimbabwe', Journal of Modern African Studies 37(4), 643-668. http://dx.doi.org/10.1017/S0022278X99003171

Lambright, M.K., 2005, 'Party systems and democratic consolidation in Africa's electoral regimes', Party Politics 11(4), 423-446. http://dx.doi.org/10.1177/ 1354068805053211

Lapalombara, M.W., 1966, The impact of parties on political development. In political parties and political development, Princeton University Press, Princeton, NJ.

Larmer, M., 2011, Rethinking African politics. A history of opposition in Zambia. Ashgate Publishing Limited, London.

Lewis, P.M., 1992, 'Political tradition and the Dilema of Civil society in Africa', Journa of International Affairs 46(1), 31-54.

Linebaugh, P. \& Rediker, M. 2000, The Many-Headed Hydra: Sailors, Slaves, Commoners and Hidden History of the Revolutionary Atlantic: Journal of World History 13.2 (2002) 512-514 (https://muse.jhu.edu/article/18469/pdf)

Lipset, M.S., 1959, 'Some social requisites of democracy: Economic development and political legitimacy', American Political Science Review 53, 69-105. http://dx.doi. org/10.2307/1951731

Lipset, S.M., 2000, 'The indispensability of political parties', Journal of Democracy 11(1), 48-55. http://dx.doi.org/10.1353/jod.2000.0016

Macquarrie, J., 1966, Principles of Christian theology, Charles Scriber's Sons, New York.

Mainwaring, S., 1995, Building democratic institutions: Party systems in Latin America, Stanford University Press, Stanford, CA.

Martin, R., 2000, 'African Multi-Partyism and the quest for democratic alternatives: Ugandan elections past and present', in J.A. Hesseling (ed.), St. Martin's Press, New York.

Mbikusita-Lewanika, A., 2003, Hour of re-union: Movement for multiparty democracy: Conception, dissension and reconciliation. p.p 448 African Lineki Courier press, Mongu-Lealui.

Mckim, D.K. (ed.), 1992, Encyclopedia of the reformed faith, St. Andrew Press, Edinburgh.

Mbiti, J., 1979, Concepts of God in Africa, East African Educational Publishers, Nairobi.

Mpashi, S.A., 1970, 'Akatabo ka baice' (Written in Bemba). National Education Co. of Zambia press, Lusaka.

Mugambi, J., 1989, African Christian theology: An introduction, East African Educational Publishers, Nairobi.

Munshya, E., 2013, 'One Bemba, One Nation: Politics of Tribe From Kenneth David Kaunda to Michael Chilufya Sata' Elias Munshya Blog (11 October 2013) (available at http://www.eliasmunshya.org)

Mutiso, G.C.M., 1975, Readings in African political thought, Heinemann Educationa Books Ltd, London.

Muwowo, S., 2010, 'A scriptural, theological \& historical analysis of the concept of the Zambian Christian Natiohood', HTS Teologiese Studies/Theological Studies 66(1) Art. \#327, 9 pages. $h$ ttp://dx.doi.org/10.4102/hts.v66i1.327 
Muzorewa, G.H., 1985, The origins and development of African Christian Theology, Orbis Books, New York.

Mwamba, P., 2006, The Bemba political system as a basis for a sustainable development in Zambia, UKZN publications press, KwaZulu-Natal.

Nolan, A., 1995, 'Reconstructing and developing the Churches', Challenge 30, 20-21.

Nyamnjoh, F.B., 2003, 'Chieftaincy and the negotiation of might and right in Botwana democracy', Journal of Contemporary African Studies 21(2), 233-250. http:// dx.doi.org/10.1080/02589000305447

O'donnell, G. \& Philippe, C.S., 1986, Transitions from authoritarian rule: Tentative conclusions about uncertain democracies, Johns Hopkins University Press, Baltimore, MD.

Oger, L., 1991, Where a scattered flock gathered Ilondola, Missioneries of Africa, Ndola.

Olukushi, A., 1993, The politics of structural adjustment in Nigeria, Heinemann, Portsmouth.

Oomen, B., 2000, 'We must now go back to our history: Retraditionalization in Northern Province Chieftaincy', African Studies 59(1), 71-95. http://dx.doi. org/10.1080/713650973

Osabu-Kle, D.T., 2000, Compatible cultural democracy: The key to development in Africa, Broadview Press, Toronto.

Oyugi, W.O., 1988, Democracy theory practice in Africa, Heinemann, Kenya.

Padilla, R., 1979, “The Contextualization of the Gospel”in CH Kraft and T.N. Wiseley,eds., Readings in Dynamic Indigeneity. Pasadena: William Carey Library. P 286.

Parekh, B., 1993, 'The cultural particularity of liberal democracy', in D. Held (ed.) Prospects for democracy: pp. 424-429. North, South, East, West, Stanford University Press, Stanford, CA.

Parenti, M., 1995, Democracy for the few, St. Martin's Press, New York.

Pobee, J.S., 1979, Toward an African theology, Abingdon, Nashville, TN.

Pobee, J.S., 1992a, Christian faith in African context, Mambo, Gweru.

Pobee, J.S., 1992b, Skenosis: Christian faith in an African context, Mambo Press, Gweru.

Potholm, C.P., 1979, The theory and practice of African politics, Prentice-Hall, Eaglewood Cliffs, NJ.

Rahner, K., 1961, "The development of Dogma" in Theological investigations, Vol. 1. Helicon Press. Baltimore.

Rahner,K., 1978, Foundations of Christian Faith. P 120. Seabury. New York.

Rakner, L., 1992, Trade unions in processes of democratization: A study of party labour relations in Zambia, Christian Michelsen Institute, Bergen, Norway.

Rakner, L., 2009, 'Opposition weakness in Africa', Journal of Democracy 20(3), 108-121. http://dx.doi.org/10.1353/jod.0.0096

Rakner, L., Rocha Menocal, A. \& Fritz, V., 2007, Democratization's third wave and the challenges of democratic deepening: Assessing international Democracy, Assistance and lessons learned, Overseas Development Institute (Unpublished), London.

Richardson, A., 1983, A new dictionary of Christian Theology, SCM, London.

Robert, W. \& Bollen, K.A., 1990, 'Economic and noneeconomic determinants of political democracy in 1960s', in R.G. Braungart (ed.), The political sociology of state. pp. 27-45. JAI Press, Greenwich.

Roberts, A.D., 1973, A history of the Bemba political growth and change in north eastern Zambia before 1900, Longman Group Limited, Southampton.

Rodney, W., 1982, How Europe underdeveloped Africa, Howard University Press, Washington, DC.

Rohio, G.-C.M. (ed.), 1975, Readings in African political thought, Heinemann, London.

Rosh, L.S., 1988, 'The structural constraints of the World- Economy on National Political Development', Comparative Political Studies 21(2), 171-199. http:// dx.doi.org/10.1177/0010414088021002001
Rostow, W.W., 1960, The stages of economic growth: A Non- Communist Manifesto, Cambridge University Press, Cambridge.

Runia, K., 1969, 'The Biblical View of the State', In Confessing Christ in Doing Politics. The Institute for Reformational Studies press. Potchefstroom.

Rustow, D.A., 1970, 'Transitions to democracy: Toward a dynamic model', Comparative Politics 2, 337-363. http://dx.doi.org/10.2307/421307

Saidman, S.M., Lanoue, D.J., Campenni, M. \& Stanton, S., 2002, 'Democratization, political institutions, and ethnic conflict: A pooled time- series analysis, 1985-1998' Comparative Political Studies 35(1), 103-129. http://dx.doi.org/10.1177/ 001041400203500108

Sartori, G., 1976, Parties and party systems, Cambridge University Press, Cambridge.

Schillebeeckx, E., 1963, Christ the sacrament of the Encounter with God. Sheed and Ward. New York.

Schmitter, P.C., 1997, 'Civil Society East and West', in L. Diamond et al. (eds.), Consolidating the third wave democracies: Themes and perspectives, Johns Hopkins University Press, Baltimore, MD.

Setiloane, G.M., 1976, The image of God among the Sotho- Twana, Balkema, Rotterdam, p. $138 \mathrm{ff}$.

Smith, D.C., 1998, 'Africa's New Bloc', Foreign Affairs 77(2), 80-94. http://dx.doi. org/10.2307/20048790

Smith, R., 1988, Kingdoms of the Yoruba, 3rd edn., University of Wisconsin Press, Madison, WI.

Sosala, H.K., 2014, The Discent of the Bemba Tribe. Unpublished.

Svasanad, V.R., 2002, 'Political parties and democratic consolidation in Africa', Democratization 9(3), 30-52. http://dx.doi.org/10.1080/714000266

Sybertz, J.H. (ed.), 1996, Towards an African narrative, Orbis Books, New York.

Taylor, G., 2002, If you have ears, Salty Print, Woodstock.

The politics of tradition: Continuity and change in Northern Nigeria 1970, The politics of tradition: Continuity and change in Northern Nigeria, 1946-1966, Princeton University Press, Princeton, NJ.

Tocqueville, A.D., 1898, Democracy in America, The Century Company, New York.

Torres, K.A.-K. (ed.), 1979, African theology en route: Papers from the Pan-African Conference of Third World Theologians December 17-23, 1977, Accra, Ghana, Orbis Books, New York.

Twaddle, H.B., 1995, 'Uganda: The advent of No- Party Democracy', in J.-A. Wiseman (ed.), Democracy and political change in Sub-Saharan Africa. Routledge. New York.

Varshney, A., 1998, 'Why democracy survives', Journal of Democracy 9(3), 36-50. http://dx.doi.org/10.1353/jod.1998.0053

Verba, G.A., 1963, The civic culture: Political attitudes and democracy in five nations, Princeton University Press, Princeton, NJ.

Villoro, L., 2000, 'On consensual democracy: Concerning Kwasi Wiredu's ideas', Polylog 2. pp. 1-5

Walle, M.B., 1997, Democratic experiments in Africa: Regime transitions and comparative perspective, Cambridge University Press, Cambridge.

Whitaker, S.C., 1970, The politics of tradition: Continuity and change in Northern Nigeria, 1946-1966. Princeton University Press, Princeton, NJ.

Wiredu, K., 1996, Cultural universals and particulars, Indiana University Press, Bloomington, IN.

Wiredu, K., 2000, On Consensual Democracy. Indiana University Press. Bloomington IN. Zambia, G., 1996a, Constitution of Zambia (Amendment), Act No.18.

Zambia, G., 1996b, 'Elections and human rights in the Third Republic', Human Rights Watch Vol. 8, No. 4 (A). 